\title{
The Bay of Pigs: REVISITING TWO MUSEUMS
}

\author{
PETER ReAd AND MARIVIC WYNDHAM
}

Public History Review, Vol 14, 2007, PP80-96

\begin{abstract}
Che Museum of Playa Giron - the Bay of Pigs - in the region of Cienega De Zapata, Cuba, celebrates the repulse of Brigade 2506 as the first reverse of United States (US) imperialism on the American continents. The equivalent
\end{abstract} Brigade 2506 Museum in Miami, dedicated to and maintained by the members of Brigade 2506, celebrates defeat at the Bay of Pigs as moral victory for the Cuban exile community. The forces were indeed implacable foes. Yet both museums present the common theme of the confrontation between forces of good and evil. Both celebrate the common philosophy that dying for one's country is the greatest good a citizen may achieve. Both museums fly the common Cuban flag. Finally, both museums share a common culture and identify a common enemy: the United States of America.

Before examining the narratives of either museum we need to understand what actually did take place at the Bay of Pigs between 13 and 18 April 1961.

By the end of 1960, two years into revolutionary power, Castro had strongly consolidated his forces. In popular appeal and in the organization of the citizen militia, his regime had become much more formidable than was realised by either the exiles or the CIA. Though a sizeable number of dissidents worked or were ready to work against him, and though he had yet to declare himself a communist, eastern bloc arms were already flowing strongly into the country. Castro's revolutionary army, though not well trained in the use of these light and heavy weapons, was huge compared to anything the Miami exiles were likely to muster. His few naval craft and dozen serviceable war planes were matched by the exiles' expectation that the US would be willing put some of theirs at the Brigade's disposal: the exiles themselves had none.

Despite the huge imbalance, the counter-revolution, that is, the invasion designed to unseat Castro, was certainly expected. By the end of March 1961 Castro was waiting, minute by minute, for the first intimations of the assault which he knew would come soon. But when and where? Which would be the decoys and which the real assault force? And at which points would the Americans and what he called the 
'mercenaries' strike? The Brigade members were not, of course, mercenaries, but volunteers backed by a large arsenal, from revolvers to tanks, supplied by the US.

The exile army comprised 1500 troops of the volunteer Brigade 2506, not a large proportion of the 80,000 able-bodied Cuban men already in exile. It contained very few professional soldiers, mostly young men in business or university, untrained in arms until formally enlisted in January or February 1961. By April they waited at the invasion stepping off point in Guatemala, united in their desire to overturn Castro, to recapture the island for their families and the exile community and to restore the 1940 constitution. They had no uncertainty as to whether they would succeed, and when, from January, they began to farewell their friends, it was no secret they were bound for advanced training in Central America. They understood that everyone, civilians and soldiers, would be reunited in Cuba; for after the military victory was won and the provisional government established, all the exiled Miami Cubans would be returning home.

The campaign to retake the island had been formally endorsed by Eisenhower in March 1960, six months before the end of his second term. The incoming President was John F. Kennedy, no older, as Soviet Premier Nikita Kruschev tartly put it, than his own eldest son. In January 1961 his new administration was still unsure of itself, somewhat over-respectful of Eisenhower's military opinion and the previous planning and unfamiliar with how to manage relations between the State Department, the United Nations, the Defence Department, the Joint Chiefs of Staff and the CIA. The administration was even unfamiliar with bureau-speak: Kennedy's inner circle did not understand, until several weeks after the Bay of Pigs invasion, that the true meaning of the Joint Chiefs of Staff opinion of 'a fair chance of success' was in fact only thirty per cent. Influenced by the current political philosophy 'Liberal anticommunism', and fearful of the Soviets raising the stakes in Berlin if the US acted too openly in Cuba, Kennedy vetoed the initial invasion plan at Trinidad de Cuba because it 'was too much like a World War Two landing'. In March he made it perfectly plain, publicly and face to face with the Cuban American leaders, that he would not authorise any overt US commitment beyond what was already promised.

What had been promised was the use of bases in Vieques (Puerto Rico), Guatemala and Nicaragua as training and embarkation points for troops and planes, the supply of arms, payment for the freighters for troops and arms, the supply of two large Landing Ship Docks (known as LCDs), the use of a small number of outdated warplanes, to be flown, preferably, by Cuban Americans, a number of training grounds in the United States itself, a number of 'military advisers' - and the invasion plan itself. ${ }^{1}$ By no means all of this was known to every relevant government agency. Of all the US players, the CIA understood best the dangers and the possibilities though, as it soon transpired, many critical details had escaped its over-optimistic planning briefings.

The Bay of Pigs invasion was masterminded by the CIA Chief of Operations, Richard Bissell. To the pessimists (that is, the realists), Bissell pointed to the successful overthrow of the left-leaning government of Guatemala in 1954 by a 
somewhat analogous combination of an invasion force of dissident exiles coupled with an internal revolt. Bissell argued that the guerillas trying to foster revolt in the Sierra Maestra mountains were making no progress while Castro daily grew stronger. A large number of dissidents were evidently ready to rise in revolt. His infective optimism and senior position caused other officials to encourage their Cuban allies, more confidently than they should have, of the probability of ultimate US intervention. Surely, the exiles themselves believed, the US would not permit things to go badly wrong.

Bissell's 'Operation Pluto' called for troops and equipment to be ferried from Guatemala by five lightly armed freighters and two heavy landing craft large enough to carry tanks. They would stand offshore during the night invasion providing first and follow up supplies, ammunition, logistics and communications, protected by aircraft. The landings themselves were to take place on the south coast of Cuba in the area known as Cienega de Zapata, 'the Great Swamp of the Caribbean'.

Though chosen as the invasion point so late that the senior officers had no time to 'war game' the plan, the location seemed sound tactically. It was within a few hours drive from Havana. It was underdeveloped, even backward, and believed to contain few people. Its swampy terrain and spiky, almost impenetrable vegetation should force the retaliatory Castrista troops along its three narrow access roads. The landings themselves would be at Red Beach (Playa Larga, at the extreme inland end of the Bay of Pigs), Blue Beach (Playa Giron) and Green Beach, a point thirty kilometres east of Giron, to cut the road to Cienfuegos. The fourth prong of the assault was to be three co-ordinated paratrooper landings twenty kilometres inland, centring on San Blas. Simultaneously the guerillas, and what was assumed to be a huge number of dissidents, would emerge from either forests or city apartments to continue the internal overthrow of the regime.

The successful landing of a sizeable amphibious assault force on unknown beaches is the most difficult military manoeuvre of all to accomplish - and even more so at night. The plan, indeed, might have been sound, even ingenious, but in the end success depended on complete mastery of the air both to protect the landing craft and to harass the troops which would undoubtedly be rushed from Havana to oppose the Brigade. Other potential problems were not seriously discussed: the inadequate airstrip, the massive imbalance in troop numbers and the unknown number of Cubans who might - or might not - join the Brigade after the invasion. Other problems were not discussed at all. It was assumed rather than demonstrated that hardly anyone lived in the Cienega de Zapata region, that the dark shadows appearing in air reconnaissance photos of the planned invasion site at Playa Giron were seaweed, that the Brigade members, in the event of difficulty, would be able to fight their way to the Escambray mountains to set up guerilla bases - even though they stood many kilometres away across almost impenetrable country.

The plan continued: the area of Brigade control, some sixty kilometres wide, would be held for at least seventy-two hours until members of the Provisional Government in Exile flew from Miami to establish themselves. At this point the 
invasion could be officially regarded by the United States as legitimate. Protection would need to be continuously provided from war planes and ships. Supplies would continue to be landed for thirty days.

Things went wrong for the Brigade even before the landings. Operation Pluto's preliminary phase was the intended destruction of the small Cuban Air force by Brigade pilots, aided by some Americans. Two days before the invasion they would use sixteen twin engined, and somewhat antiquated World War Two B26 attack bombers to destroy Castro's tiny air force then provide protection for the ground troops on shore. Shortly before the raid Kennedy, fearful of international criticism and escalation of the cold war, ordered the number of planes reduced to eight. Damaging strikes were made, for the loss of two aircraft, but the plan failed in that Castro retained a small number of T33 jet aircraft and British-built Sea Furies, against which ships had proved especially vulnerable. For the same reason Kennedy cancelled the second strike planned to coincide with the land invasion itself at dawn on Monday 17 April.

At $11.45 \mathrm{pm}$ on 16 April frogmen approached the beach of Playa Giron. Eighty metres from shore their craft encountered the coral reefs, wrongly identified by CIA reconnaissance as seaweed, forcing the men to jump overboard and wade ashore. Commander in Chief Jose Perez San Ramon ordered the $4^{\text {th }}$ Battalion ashore several hours earlier than planned. The men began hurriedly to disembark in some disorganisation. But by dawn almost all the troops and equipment planned to land that night had done so and the Castrista militia was temporarily in retreat.

Thirty kilometres away at Playa Larga, Erneido Oliva, Second in Command, successfully landed the $2^{\text {nd }}$ Battalion. Del Valle established his paratroopers as planned at San Blas and dug in to repel the expected assault by Castro's arriving troops.

By three am Castro had taken the critical, and correct, decision to attack the supply ships at first light by air. Shortly after dawn Houston, carrying a huge quantity of petrol and ammunition, was hit by rockets from a Sea Fury (a single engine World War Two attack bomber) and was beached by her captain not far from the shore. Then at 8.30am the Rio Escondido, carrying the main communications link, was attacked and sunk. Without the expected air cover, and extremely vulnerable to attack, the other three transports retreated out of range without unloading any of their supplies for what was intended to be the consolidation of the Brigade front.

Probably the battle could not at this point have been won by the Brigade unless, possibly, air protection had allowed the remaining equipment and troops to be landed. On the ground, though, Oliva first held out, then advanced against the militia. He confronted at least 2000 enemy troops at what was later known as the Battle of the Rotunda, a strategic intersection of major roads amidst the swamps and impenetrable ground.

By evening of the first full day's fighting, the paratroopers held their position at San Blas. The Brigade troops defending the three roads allowing access to the area could last indefinitely provided, firstly, that their ammunition held out and, secondly, 
that Castro did not continue his assault for twenty-four hours a day. But without air support neither could they advance. All night the Castrisas kept coming. The Brigade's orders were to resist and where necessary to stage a tactical and destructive retreat.

By mid afternoon of the second day Oliva himself was falling back before a huge advance led by tanks. That evening, almost out of ammunition, he withdrew to Giron. Late in the day supplies were dropped but most were blown off course by the wind into the sea or the inaccessible swamps. As further distraction four B26s were to attack the Castrista land forces.

The third and last day of the campaign, Wednesday 19 April, began with the scheduled raid by the Brigade planes. Two were shot down but the devastating effect of aerial attack on the incoming Castrista troops (unacknowledged in the Playa Giron Museum) indicated how air support provided by even a few B26s might have changed the battle at least long enough for all the supplies to be landed. At a war council Oliva proposed to consolidate all forces, including the paratroopers, and fight their way to the Escambray mountains to continue as a guerilla force. By mid afternoon the whole Brigade was under sustained attack from north, west and east and from the air. Kennedy ordered two destroyers to escort the supply ships in a different role: to rescue the Brigade. They did not arrive until evening, too late to save any but a few of the Brigade soldiers.

One hundred and forty Brigade members died. Almost all the rest - some 1190 were taken prisoner under conditions which varied at first between fair and appalling. Sixty of the most seriously wounded left Cuba in April 1962. But the others did not return to the US until 23 December, twenty months after the invasion and after the Missile Crisis. Bitterness over the 'betrayal' at the Bay of Pigs, the foundational narrative of the Brigade 2506 Museum in Miami, was born at Giron and fed in the long months of captivity. The Cubans, according to print sources no longer unobtainable, and whose existence is now denied, may have lost some 1650 men and 2000 wounded. Such sacrifices lend moral force to the Museum of Playa Giron's principal claim that the failed assault was the first major setback of American imperialism in the continent.

These are the essential facts as far as the now fairly extensive sources allow. The most salient facts to recall in the discussion of the Museum narratives is that the assault force was certainly expected from Guatemala but no Castrista knew where the landing or landings would occur. The US masterminded and backed the first stage of a counter-revolution which could not have taken place without the serious involvement of the exile and internal dissident communities themselves. The CIA drastically overestimated the number of internal dissidents who would, or could, take up arms in support of the Brigade and they were in any case seriously uninformed of much crucial geographical data. Despite some less than heroic actions by a minority on both sides, both forces fought with extraordinary courage and valour. None of the Cuban members of the Brigade were mercenaries. ${ }^{2}$ 
Geographically, the reference in Cuba furthest from the site of the battle itself is to be found outside the Museum of the Revolution in Havana. Here stands a tank with the inscription:

\author{
Sau 100 Soviet Tank from which \\ Fidel fired direct hits \\ on the ship 'Houston' equipped \\ by the Central Intelligence Agency $(\mathrm{ClA})$ for the \\ mercenary invasion of Giron in April 1961
}

That wouldn't have been very difficult because by the time that Casro fired his shots the Houston was already grounded and wrecked.

Two and a half hours drive from Havana lie the Zapata swamps. Though tourists flock to the beachside resorts, access is still difficult and the hinterland comparatively underdeveloped. ${ }^{3}$ The road is wide and flat and cleared twenty metres on each side before the palm trees and bananas.

Traffic from the capital still takes the visitor past the area known, oddly, as Central Australia where Castro held his advanced headquarters. A rather unprepossessing concrete monument nearby marks the site where a Castrista soldier died.

Approaching Playa Larga the visitor encounters a phenomenon familiar in Eastern Europe where publicly displayed historical artifacts and signage reinforced the prevailing political philosophy. There, memorials were utilised to preserve what the dominant (non Jewish) group wanted to remember. The communist regime insisted on the equation of communism with the long Polish struggle for independence: 'The Jews were eliminated physically by the Nazis; the memory of the Jews has been eliminated systematically by the Poles'. ${ }^{4}$ Thus the visitor views the thickening roadside monuments erected to Castrista soldiers each at the site of death. A huge hoarding depicts a regional map positioning Playa Larga and Playa Giron with the slogan:

What you will see here in this municipality is the work of the Revolution.

One passes one of the huge three way intersections - the Rotunda along which the Brigade advanced, then held the counter-attack - the scene of the most courageous and desperate fighting. A hoarding reads:

Here was waged a decisive battle towards Victory.

A concrete monument is inscribed with the names of twenty-seven Castristas who fell. A huge hoarding proclaims the site of Playa Giron as 'the first great defeat of Imperialism in Latin America'. 
The Play Giron museum is a further twenty kilometres away at the town of Buenaventura, at Playa Larga. It is a long, low building in front of which stand a Sea Fury and a tank. The signage on the aeroplane identifies it as having been used at Giron. The tank is said to be 'similar to that used by the Commander in Chief in the destruction of the ship Houston'. Entering, the visitor finds a vestibule leading to the display in the right of the building - events leading up to the battle - and the left - the battle and its aftermath.

In the center of the vestibule is collected a large display of press cuttings, the only concession to modern display design in the whole collection. On a red board some four metres long the letters GIRON are printed with a photographic montage drawn from newspapers drawn from 1950s Cuba. This is the state's nod to its version of pre-revolutionary Cuba. The cuttings on the ' $G$ ', for example, contain a sign 'Whites Section Only' showing a black man staring at a wire fence, a newspaper article beginning 'Cuba, Factory of Capitalism' and a more modern caption: 'The People reject The Eviction Law'. Underneath reads:

\section{VICTORY OF SOCIALISM.}

Another letter of the word 'Giron' contains the cutting:

New Attacks by Pirate Planes from the North

An introductory panel of the display reads:

Our National Revolutionary Militia, the Rebel Army, the National Revolutionary Police, the Revolutionary Navy joined to the efficient action of the reduced Air Force eliminated in some 65 hours the well equipped invasion sent by the United States.

This battle destroyed on the continent the myth of the invincibility of imperialism, encouraged the struggle of the American peoples and consolidated our Socialist Revolution. Testimonies of the heroic struggle waged by the Cuban people in those days figure in this museum.

The so-called mercenaries have not even been mentioned. It is the United States, not the Brigade, which this museum holds responsible for the invasion.

To enter the right hand section the visitor passes a sectioned series of life sized photographs showing the defeated Brigade members, heads mostly bowed, marching into captivity. To enter the left, one passes a similar display of Castrisas marching with heads erect.

The first part of the exhibition proper is given over to the description of the Cienega region before the revolution: 
The deep process of transformation begun by the Revolution was put in the hands of the people, gave the land to those who worked it and eliminated forever the large estates. The nationalisation of banks and big businesses, the property of Yankee monopolies and the national bourgeoisie, the Law of Urban Reform and the control of teaching concluded the phase of national liberation.

The imperialists and the bourgeoisie expelled from power began terrorist acts, diplomatic blackmail economic blockade and armed aggression with the aim of destroying the revolution.

The social structure of the Brigade is analysed:

The composition of the 'Mercenary Brigade' revealed the interests that the [now] stateless persons sought to reintroduce. An analysis of the prisoners showed that 800 of them, or their families, possessed 370,268 hectare of ground, 9666 houses and buildings, 70 industries, 10 sugar complexes, five mines and two banks. There figured also 135 ex-military from the Batistan tyranny, and 65 criminals, among them 3 known assassins and torturers. For several days television and radio carried to the country the actual interrogation of the mercenaries. The destruction of Brigade 2506 showed to the world its reactionary and criminal nature.

This first section of the display is more like a polemic on walls than a modern exhibition text. Of the paper exhibits, only one pronouncement by Castro appears to be original. It reads in part:

\section{The Country Will Resist with a Firm Foot}

At six in the morning today, the $15^{\text {th }}$ of April 1961, B 26 aeroplanes of North American make simultaneously bombarded points in the city of Havana, San Antonio De Los Baños and Santiago de Cuba according to reports received to the present...

Our country has been the victim of imperialist criminal aggression which violates all the norms of International Rights...

If the attack should be a prelude to invasion the country, on a war footing, will resist and destroy each force which intends to land on our land with an iron hand.

Further down the wall the visitor reads: 
The aerial bombardment of 15 April provoked the popular rebuff, tightened revolutionary cohesion and confirmed the unshakeable decision to defend the patria at whatever cost was necessary.

A series of coloured and detailed maps trace the dispositions and movements over the three days of the combat. Clearly the information of the Brigade's intentions and disposition has been drawn from the many books published by the former Brigade members themselves:

Our pilots and artillery shot down 11 bomber planes.

Another caption, more accurately, claims five.

The second wing of the Museum presents the stages of battle in close detail in which guns of every variety form the majority of the exhibits. In the centre of the second wing is arranged an exhibitions of light and heavy weapons used both by the Brigade and by the Castristas. One, on a Browning $50 \mathrm{~mm}$ machine gun, used by the Brigade, carries the caption:

The invading mercenaries brought with them a fabulous amount of this style of weapon in proportion to the number of men.

James Delgado, Executive Director of the Vancouver Maritime Museum, describes the exhibits as 'more a triumphant display of the enemy's weapons than a museum'.

Most of the final wall space is dedicated to the 'Heroes of Giron'. Some 170 photographed faces stare grimly from the wall, above the artifacts in glass cases of clothing, equipment, tobacco tins and letters. One photograph, for example, of a young man seeming no more than 17 , carries the caption:

\section{Luis Fernandez Rodriguez}

Born in Vedado, Havana, 21 June 1942. Worker for Artes Graficas... Participated in the Cleansing of Escambray [against guerillas in the Escambray Mountains] the third detachment of light infantry. Mechanic of Bon 1213, mobilized to Playa Giron. Died 18 April 1961

Photographs include the word FIDEL allegedly written by a soldier with his dying blood. Exhibits in this section contain a pair of high heel shoes destroyed by a bullet and the clothing of five civilian women also killed in the bombing.

The concluding caption relating to the assault reads:

At dawn on the $19^{\text {th }}$ began the simultaneous advance of our forces. From the west they spread and battered the points of enemy resistance two km from Giron, where the enemy made themselves strong. There they held up the advance and located the artillery again. In the east 
and northeast the spread of our forces enabled us to capture those trying to escape. At $2 \mathrm{pm}$ they attempted a re-embarkation which was frustrated by artillery fire and aviation. At 17.30 Play Giron fell, the last stronghold of the mercenaries.

Castro has the last word:

This day Yankee Imperialism suffered in America its first great defeat, according to the Commander in Chief, Fidel Castro.

Thus the Cuban State presents its account of the campaign.

While the military details of the campaign are reasonably accurate, the historical interpretation, as everywhere in Cuba from museums to cemeteries, follows the Castrista position. In a lecture to a national Cuban Congress in 1999, one of Castro's key subordinates, Jose Ramon Fernandez, drawing upon a number of named US and Brigade histories, told a very similar story. ${ }^{6}$ Both the museum's and Fernandez' account hammered, above all, at the twin themes: the supposedly mercenary status of the Brigade soldiers and the profound involvement of the US.

It is the interpretation of the casualties that is most at fault. The number of Castrista death is likely to have been much closer to 2000 than the 200 claimed in the Museum. The prisoners are asserted to have been treated well but no mention is made of the nine men who died in an overcrowded airless sealed truck taking them to Havana. ${ }^{7}$ Everywhere, in defiance of good sense, the Cuban born Brigade members are labeled 'mercenaries'. It is not at all obvious, given the enormous list of farms, houses and businesses which they had allegedly lost, why the exiles would have had to be paid to attempt to retake their lost possessions. The soldiers need, for propaganda purposes, to be mercenaries because the principal purpose of the Museum is to denigrate the failure of 'Yanqui' imperialism.

Finally, the Castrista interpretation of the assault ends on the 18th of April. Yet for the Brigade members themselves, the second and equally important part of the story begins at the moments of surrender. The standard account of the Brigade commanders, The Bay of Pigs, published in 1964, devotes a further 150 pages to the period of imprisonment and negotiation by the Cuban Families and the Tractors for Freedom committees. Imprisonment in a number of Cuban locations bonded the Brigade men more much tightly than the three-day battle itself.

It was in twenty months of intimidation and interrogation in Cuban prisons, when a different outcome of the Missile Crisis might well have ended their lives, that the strongest bonds between the Brigadistas were formed. They applaud themselves, with justification, for having answered a call to arms and endured bitter defeat while still achieving their own moral victory in withstanding intimidation in clandestine and public trials. Here courage was tested, assessed and enshrined in their collective memory. They saw themselves in extremis, emerging with a foundational narrative of coherence and moral conviction. Their victory comes at the expense of those Brigade 
members who remained on the ships, and worse, those who merely talked of their patriotism and stayed in Miami.

At midnight on every seventeenth of April the remaining Cuban-American brigadistas meet at the Cuban memorial Boulevard in the Cuban American downtown in Miami. Here at first, in silence, the ageing soldiers recall their comrades, the event and, in particular, the martyrs. They gather round the concrete column topped by an eternal flame surrounded by two chain barriers, the innermost supported by four sixinch shells. The inscription reads, in Spanish:

CUBA
To the
Martyrs
Of the
Assault
Brigade
17 April
1961

Here stands, then, no monument to the Brigade itself but to its martyrs. Patria $o$ Muerte, Country or Death, resonates as strongly here as it does in Cuba. Que morir por la patria es vivir, to die for the patria is to live, is the key element of the Cuban national anthem. Any soldier who had written 'La Brigada' with his dying blood would be honoured here as surely as the Castrista hero.

The service ends. The brigadistas will meet here tomorrow for a more convivial gathering of memorialising and celebration. They pride themselves that after fortyseven years of Cuban American threat, menace and empty talk, they are the only ones who have actually done anything about rescuing their country from the Fidelistas. And it is now clear, after more than four decades of futile exile rhetoric, that that there will be no more attempts. Miami today holds more than a million Cuban exiles. The embarrassment felt by younger exiles that the Assault Brigade was both the first and last permeates macho Cuban Miami society. Yet for the overfifties the Brigade history is both a source of patriotic pride and an unwelcome reminder of their own failures. That essential dichotomy underpins all that the Brigade stands for, between those who went and those who only talked.

A visit to the Brigade 2506 Museum in Little Havana, Miami, is part of the Florida Cuban Heritage Trail. ${ }^{8}$ Described in the brochure as 'quaint' and 'homelike', it is housed in an unpretentious bungalow in Miami's Little Havana. From outside it resembles a house or family museum: and so indeed it is - the family of Brigadistas. Perhaps, too, like the exiles who died and were buried in simple graves in the early 1960s, they expected only a short stay in Miami. The Brigadistas raised funds for its purchase by pooling their financial resources. Its is clear that no professional curator has worked here. Rather, the presentation seems to be the work of the Brigade members themselves. The presentation, too, most unusually makes no overt 
connection between the Brigade and the usual Cuban antecedents of the War of Independence heroes Maceo or Martí. The first martyr whom the visitor confronts is not a hero of the Spanish war but Nestor Izquierdo, the first Brigade soldier to die in combat. The Brigade is writing its own contribution to Cuba's continuing war of independence.

Just inside the entrance, where, equivalently, the Playa Giron museum presents the massive display Heroes of Giron, are testimonies to the present and past Brigade leadership. In 1996 a discordant note resounded in the tiny space. Amidst the solemnity stood a large, garish Coke machine and a dwarf statuette of Uncle Sam, inviting the visitor to drop ash and cigar stubs into his hat. It is intentionally disrespectful. Today that Uncle Sam has gone. But another, only slightly less disrespectful caricature occupies the same space. The awkward, ambiguous tone which foreshadowed the anti-Americanism of the 1996 narrative is no more resolved than a decade ago. ${ }^{9}$ It is no accident that the Museum's most recent website describes one of its purposes as outlining the changes in the lives of millions of people that live in the Americas as a result of 'this fiasco'.

Leaving the vestibule, the visitor walks through the Dr Manuel F. Artime Library. The Library's conference table and thousands of dark shelved books establishes the credentials of sobriety, rationality and truth of those who were once young and angry and who later became the pillars of the male Miami exile society. Many conference rooms in Cuba, thanks to the Blockade and to the general impoverishment of cultural facilities, today resemble nothing better than undergraduate meeting rooms of Australian universities. The dignified Artime library resembles a company Boardroom, representing, accurately enough, the minor family corporation which the Brigade has become. Here, then, is a family sanctuary as much as museum. Here the Cuban virtues of courage in adversity are displayed and celebrated.

The central hall, the dark brown and white Chamber of Arms, continues the theme of serious reverence. Ten rows of chairs are arranged like a chapel, looking to an altar-like depiction of a running figure, bayonet outstretched. Above the figure is the banner on which is inscribed Brigada Asalto. A Cuban flag adorns the right hand side, a US flag, required by law, is on the other. To the right is furled the flag of the Brigade itself, presented to Kennedy on his promise that it next would fly in a free Cuba, embargoed amongst his state possessions after his assassination and only returned to the Museum after an unseemly legal battle with the curators of the Kennedy Library.

On the wall facing the audience, reaching to the floor and above the doors, are fixed the $140 \mathrm{~A} 4$ sized black and white photographs of the martyrs, under the modestly lettered caption 'Martires de Giron'. These identically serious young men present themselves mostly in suit and tie: there was neither time nor opportunity to photograph them as they prepared themselves for training in Guatemala. To the right stands a three-dimensional full size sculptured soldier. The ambience presents the climax of struggle, yet the Chamber remains a room of mourning. The icons are not triumphant young soldiers in combat fatigues but dead heroes presided over by 
priests of equal stature, held in the temple of respect and worship. On the left are photographs of the martyrs, those who died during the assault or in prison. On the right are photos of the 'Heroes', jowly, respectable, middle aged or older.

The guide, a proud brigadista, makes clear what is already implied in the display: that one only becomes a Hero through death. For even a brigadista, regrettably, is capable of unworthy action later in life. Only on death does he become incapable of dishonourable action; only now does he become a Martyr. What would be dishonourable? The answer is clear for some whose names are proscribed on an undated list. To have been a dialoguero, one who went to dialogue with the Cuban government, is an action heinous enough to the Brigade Association management to have one's name expunged not only from the rolls of honour but from Brigade memory. Another list names two men expelled for having flown from Cuba to negotiate the release of their fellow prisoners but who did not, as promised, return. The spaces filled not with a photograph but the Brigade emblem reveals, at this most solemn site, the bitter divisions within the exile community.

On the third wall of the Chamber of Arms are the historical exhibits, principally narrating the events after the surrender, photographs of capture, imprisonment, interrogation, release and return. The actual details of the three-day battle are much less clear than in the Cuban museum, for the Brigade's claim to moral victory lies not in what happened on the beaches. Only key pictorial incidents follow, such as the shooting of the US pilots:

\begin{abstract}
ASSASSINS
Bodies of Pete Ray and Francis Leo Baker on the floor of the Australian Sugar Mill after been shot in the head by Fernandez Mel. Both pilots were captured alive but wounded and cold bloodily executed.
\end{abstract}

And:

Body of a Brigade tanker crew killed in action, his boots were taken as souvenirs by the Castro communist forces.

The aftermath:

Ten die of Hunger and Thirst

A third 'key' incident is the moment during the trial of the defeated exiles, at which the soldier Afro-Cuban Tomas Cruz was asked by Castro why he had returned when under Batista he hadn't been allowed on the beaches. He replied: 'I did not come to Cuba to swim on the beaches.'

The brigade, given its level of American support, could hardly have succeeded: the strong implication holds that Kennedy's administration never gave it a fair go. By far the most space is given over to the return of the prisoners to Miami, more 
significant to the brigadistas than the assault itself. Photographs depict the queuing in Havana to board the aircraft, scenes inside the aircraft and people disembarking and greeting relatives. Almost every Miami Cuban over fifty five recalls the extraordinary moment of silence when, on 14 April 1962, the planes carrying the badly wounded arrived at Miami airport: Gloria Morena, then 13 years old, recalls:

Imagine! They made it! They were on our side! We saw the red carpet with Cuban and American flags. It was really the return of grand grand heroes. I just remember the long strip of red carpet leading to the stairs, and this gasp of expectation and joy. Joy. I think there was silence first. In the midst of is much tragedy we had extracted these lives. As soon as that door opened. And each stood at the top of the stairs with Colonel Bogey playing, and they saluted the flag as best they could. Some were on crutches, some had no legs, some had no right arm to salute with. Such pride, they were standing as tall as they could even in the wheelchair. It was done very slowly. Each man was given his moment. There I remember women in the crowed fainting, just fainting from sheer emotion, sisters and grandmothers. We were so proud. It was really a moment when all the best of Cuban history had taught us, we were witnessing it again. They were our mambices [freedom fighters against the Spanish] of our generation. To me it was the most moving moment in the whole of the Playa Giron saga. To see these men who had come home, and they were proud and they were saluting the flag. They didn't come in a despondent mood, they came in a triumphant mood and I think that triumphant mood has carried the Brigade ever since. ${ }^{10}$

Yet none of the joy felt so strongly by seemingly everyone present is alluded to. Nor does the visitor feel the tumultuous occasion as the guard of honour formed for the President by the Brigade members as he entered the Miami Orange Bowl. Nor is the roar of approval which followed his promise to return the flag to a free Cuba. Rather, the photograph of Kennedy receiving, from San Ramon, the flag which had flown for three days at the Command Post is reproduced with the ominously simple caption:

I can assure you that this flag will be returned to this Brigade in a free Havana.

The anti-Americanism is implied in what is not said. The principal emotion which the Brigade museum communicates is the quiet responsibility of the mature macho.

In this museum, as in Cuba, there is no moral uncertainty. Conclusions are already drawn, there can be no alternative view. Silences, omissions, oblique references to Kennedy's alleged failed support replace explicit condemnation. But the message is clear. If there is an enemy at all within these walls it is not the Castristas nor the CIA but Kennedy himself. The President is shown shaking hands with the 
soldiers whom he had earlier - so runs the least sympathetic interpretation betrayed.

A display of congressmen's letters in tribute to the Brigade accentuates the dichotomy between what the President did and what he should have done. Outside in the parking lot, in 1996, an old thirty-foot launch lay becalmed on the asphalt. She was 'La Libertad'. The guide explained that she had been used on a number of clandestine missions to Cuba and that he would next captain the boat to the island after liberation. Thereafter he would never set eyes again upon the US. Such a provenance, written out, would be unacceptable: self-censorship is part of the unwritten contract between the Brigade and the US administrations. Nor have such anti-American sentiments diminished over time. A statement released in March 2005 by the Brigade leaders promises that although they 'do not know hatred', they 'reject any kind of dialogue with the dictatorship' but add, significantly, that 'they will not permit any foreign interference, whatever it may be, that violates the sovereignty of the republic of Cuba'. ${ }^{11}$

The more subtle messages await the sharp-eyed visitor who has time to talk to the guides and read the closely-typed documents. A pamphlet of the time disingenuously describes the brigade as composed of many races: Argentinians, Peruvians, North Americans, Cubans, 'some military personnel of Castro's army' and 'some from the former army', as if the force was an international peace-loving, anticommunist, well-meaning crusade. The overthrown president Batista's name is nowhere mentioned in the captions. Yet a file marked 'Your eyes only', recently released from the US Archives, reveals that the successful brigadistas were to dissociate themselves clearly from the previous government. It was sound advice: few Cubans remaining on the island would have welcomed a return of the Batistianos after a Brigade victory. The guide - but no caption - explains 'nearly all of us were trained by Batista's army or police - that's why we went back!'. Elsewhere in Miami the visitor may even learn a few points not mentioned in the display. A city plaque at some distance from the museum entitled 'Impact of the "Bay of Pigs" on Miami', reads that the failed assault:

did not destroy the dream of returning to Cuba but it did make many more look at Miami as more than a temporary refuge. Careers, education and the starting of new lives became important concerns of the refugees.

Probably all the brigade members would privately admit this to be true but not everyone would wish it said so publicly.

Our introduction proposed that the museums share a common culture. One element, as we argued in our 1998 article in this journal, is machismo. ${ }^{12}$ Some of the faces displayed in the Chamber of Arms of the Brigade Museum appear, though unidentified, in photographs of the young revolutionaries of 1956-9 in the Museum of the Revolution in Havana. Some photographs appear, though with different captions, in both the Brigade and the Bay of Pigs museums. All the Brigade members lived in 
Cuba in the 1950s. Their leaders were prominent pro-Castro revolutionaries before and soon after January 1959. The now deadly foes drank at the same well of armed struggle, brotherhood and guns. Of the thousands of revolutionary Cubans who later called themselves socialists, patriots, communists or democrats, many had wanted Batista to be overthrown and had shouldered arms together to that end. They fought under the same flag, even after they became enemies. Nearly all the brigadistas at the time of the invasion had family members still living on the island. Some were taken prisoner by their own cousins. Castro knew all the Brigade leaders by name. Once or twice he came to their cells to chat, brandish a pistol at them, offer a drink or ask them why they had changed sides.

Equally important today is a shared anti-Americanism. While Castro's name as 'villain' is scarcely mentioned, Kennedy's - pejoratively - is everywhere. In the Brigade Museum the President makes the (unsourced) remark as the campaign began: 'If it's Cuba they want to go to, dump them there'. At some points the message is more explicit. A brigade soldier is seen to state: 'the people we trusted let us down'. At other points the opprobrium is universal: 'The loss [of the Brigade] has caused death, unrest and instability for South American, Central American, Caribbean and African countries for the past four decades'. The Old Guard will not resile from its perceived betrayal. 'We were your allies, your cousins, your family', whispers the museum, 'yet you would not help us in our hour of greatest need'. Featured is an account of Perez Garcia, the Cuban patriot who became the most highly decorated soldier in the Pacific theatre of World War II: look how much, runs the implication, Cubans have helped the Americans in battle.

Nothing is to be found here of the re-assessment of historical interpretations in US museums affecting, for example, slavery. For most of the twentieth century the US heritage industry suffered from slavery-amnesia. In the interpretations of most museums, Civil War soldiers fought to save the Union rather than to end slavery. Tour guides of southern mansions referred to 'servants'; slave quarters were not part of the tour. Guilt and shame seemed to prevent a more open discussion. The attitudes of 'middle America' began to change only after television and film spectaculars like Roots and Amistad. ${ }^{13}$ Yet it is not as though the Brigade view of itself is unchallenged. The John F. Kennedy Presidential Library and Museum website obliquely blames the landing place, Eisenhower, the CIA, the Miami exiles and the Cuban people who failed to rise in support and features a photograph Kennedy at the Miami Bowl. ${ }^{14}$

While the leadership of each museum remains no new interpretation is at all probable. Playa Giron will remain locked in a modern-looking but in fact oldfashioned model of public propaganda that is by no means shared by many Cuban youth. ${ }^{15}$ In Miami, the Brigade Museum is more likely to be by-passed without change. A new Bay of Pigs Museum, coupled significantly with the history of the Cold War, is planned by a younger generation of Cuban exiles. Its curators seem less preoccupied with individual heroism while seeking to set the events in a wider Latin American context. They aim to: 
create a modern, world-class Cold War museum in Miami honoring the UStrained Brigade 2506's heroic fight against Fidel Castro's communist dictatorship in Cuba. The high-tech, multimedia Museum will preserve the history of the dramatic Bay of Pigs invasion and describe Brigade veteran actions in other conflicts with Castro worldwide. It also will honor others who fought for freedom in Cuba. The museum will place all these events in the broader Cold War context and show how Miami was on the front lines in the battle for freedom. ${ }^{16}$

The Playa Giron Museum is accurate in the microcosmic analysis of the campaign but fails grossly in its interpretation of the reasons for the invasion. Its antiimperialism, for political and strategic reasons, is markedly overstated. The Brigade Museum excludes every emotion except that of quiet and corporatised manly virtue. What unites both museums is the sense of moral victory, not over each other, but over the United States of America.

\section{ENDNOTES}

1 Eduardo Garcia, head of the only Cuban shipping line still trading with Havana, provided five freighters, contracted to the CIA, for 'direct operating costs' only.

2 This section has been drawn from a variety of sources, including Lawrence Freedman, Kennedy's Wars, OUP, New York 2000, Ernest May and Philip Zelikow, The Kennedy Tapes, Belknap Press, Harvard University Press, Cambridge, Mass., 1997, Peter Wyden, Bay of Pigs, Simon and Schuster, NY 1979 , Haynes Johnson, with Manuel Artime, Jose Perez, San Roman, Erneido Oliva and Enrique Ruiz-Williams, The Bay of Pigs, Norton and Co, New York, 1964, Albert Persons, Bay of Pigs, McFarland and Co, Jefferson NC, and Nestor Carbone, And the Russians Stayed, William Morrow and Co, New York, 1989.

3 The most popular tourists spots are a crocodile farm and the recreation area spreading along the road from Playa Larga to 'Blue Beach' at Giron.

4 S. Kaprallski, 'Battlefields of memory: Landscape and Memory in Polish-Jewish relations', History and Memory, Fall 2001, 13, pp35-50.

5 For Delgado's account of the Cuban Bay of Pigs Museum see James P. Delgado, 'Back to the Bay of Pigs', US Naval Institute [Journal], Proceedings, April 2001;

www.usni.org/Proceedings/Articles01/PROdelgado4.htm; accessed 5 November 2006.

6 José Ramón Fernández, 'La Invasion de Playa Giron, Presentado en el proceso judicial por la Demanda del Pueblo de Cuba Contra el Gobierno de Estados Unidos por Daños Humanos, llevado a cabo ante la Sala de lo Civil y Administrativo del Tribunal Pronvincial Popular de Cuidad de la Habana en mayo de 1999', in José Ramón Fernández and José Pérez Fernández, La Guerra de EEUU Contra Cuba, Ocean Press, La Habana, 2001.

7 Johnson et al, pp188-9.

$81821 \mathrm{SW} 9^{\text {th }}$ Street, SW.

9 For a brief description of the Brigade Museum in 1996, see M. Wyndham and P. Read, 'Two Museums', Public History Review, vols 5/6, 1996-7, pp125-35.

${ }_{10}$ Interview, Miami, 2004.

11 Asociación De Veteranos de Bahia de Cochinos. Brigada de Asalato 2506; ww.brigada2506,com.conf032205.htm, accessed 10 November 2006.

12 Wyndham and Read, 'Two Museums'.

${ }^{13}$ Ruffins, pp396-434.

${ }^{14}$ www.jfklibrary.org/Historical+Resources/JFK+in+History/JFK+and+the+Bay+of+Pigs, accessed 21 November 2006.

${ }^{15}$ It is unwise to quote opinions verbatim or to name speakers but the authors have obtained a clear sense of dissatisfaction with the current leadership (though not necessarily the prevailing political philosophy) among young Cubans.

${ }^{16}$ www.bayofpigsmuseum.org/vision.html, accessed 21 November 2006. 